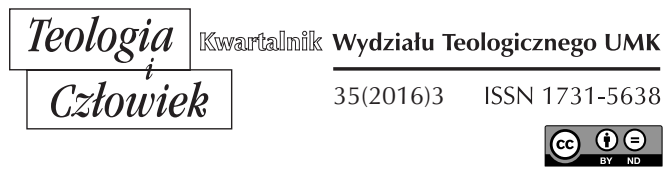

KS. STANISŁAW SUWIŃSKI*

TORUŃ

\title{
WEZWANIA NOWEJ EWANGELIZACJI I DAR ŚWIATOWYCH DNI MŁODZIEŻY
}

DOI: http://dx.doi.org/10.12775/TiCz.2016.034

\section{WPROWADZENIE}

W homilii, którą Jan Paweł II wygłosił 9 czerwca 1979 roku podczas Mszy świętej w ogrodzie klasztornym w Sanktuarium Krzyża Świętego w Krakowie-Mogile, padły słowa:

Niegdyś ojcowie nasi na różnych miejscach polskiej ziemi stawiali krzyże na znak, że dotarła już do nich Ewangelia, że rozpoczęła się ewangelizacja - i że trwa nienaruszona. Z tą myślą postawiono też ów pierwszy krzyż w podkrakowskiej Mogile - w pobliżu Starej Huty. Kiedy postawiono opodal tego miejsca nowy, drewniany krzyż, było to już w okresie Millennium. Otrzymaliśmy znak, że na progu nowego tysiąclecia - w te nowe czasy i nowe warunki wchodzi na nowo Ewangelia. Że rozpoczęła

* Ks. dr hab. Stanisław Suwiński jest kapłanem diecezji toruńskiej i adiunktem w Katedrze Teologii Moralnej i Duchowości w UMK w Toruniu. W swoich badaniach zajmuje się duchowością chrześcijanina oraz różnymi kierunkami jej rozwoju (stanislaw. suwinski@umk.pl). 
się nowa ewangelizacja, jak gdyby druga, a przecież ta sama co pierwsza. Krzyż trwa, choć zmienia się świat ${ }^{1}$.

Zatem pod pojęciem „nowa ewangelizacja” kryje się odzew Kościoła wobec kryzysu, z jakim zmaga się obecne pokolenie. Na teraźniejszą sytuację świata wpływ miały wydarzenia z przeszłości. Dwie wojny światowe, prześladowania, stosowanie przemocy spowodowały, że obecna cywilizacja boryka się z nowymi problemami, a zarazem stoi wobec nowych wyzwań, jakimi są trwanie przy Kościele i budowanie przyszłości na fundamencie żywej wiary. Misją Kościoła jest umacnianie wiary ludzi poprzez takie przekazywanie treści, które będzie odpowiadać mentalności dzisiejszego pokolenia.

W zmaterializowanym świecie, gdzie wartość życia ludzkiego schodzi na dalszy plan, a rozpowszechnia się sekularyzm i ateizm², ważna jest troska Kościoła o wszystkich ludzi, a szczególnie zwrócenie się ku młodzieży - będącej przyszłością świata - i wskazanie jej dróg wiodących do dalszego życia z Bogiem. To od tego, jak młodzi zostaną uformowani, wychowani w rodzinie, zależą przyszłe losy Kościoła. ${ }^{3}$

Światowe Dni Młodzieży są jedną z dróg realizacji tego wezwania nowej ewangelizacji. Młodzież z całego świata spotyka się z papieżem, by odkryć drogę prowadzącą za Chrystusem. Te wydarzenia są istotne dla życia Kościoła, ponieważ młodzi ludzie odkrywają drogę prawdy. Podczas tej formacji duchowej młodzież może usłyszeć wiele świadectw, które są pomocne w rozwoju chrześcijańskiego życia. Światowe Dni Młodzieży są darem, dzięki któremu można odkryć nowe siły do ożywienia wiary.

$\mathrm{W}$ dzisiejszych czasach młodzi ludzie zmagają się z różnymi pokusami, mają wiele lęków i trosk ${ }^{4}$. Należy wpoić im najważniejsze wartości, przekazać swoje doświadczenia, aby mogli zbudować przyszły świat, który

1 Jan Paweł II, Homilia w czasie Mszy św. odprawionej przed opactwem OO. Cystersów w Mogile, 9.06.1979.

2 Zob. G. Kuby, Globalna rewolucja seksualna, likwidacja wolności w imię wolności, tłum. D. Jankowska, J. Serafin, Kraków 2013, s. 76-79.

${ }^{3}$ Zob. Jan Paweł II, Adhortacja apostolska o zadaniach rodziny chrześcijańskiej w świecie współczesnym Familiaris consortio, 22.11.1981, nr 36-41.

${ }_{4}^{4}$ Zob. tenże, Posynodalna adhortacja apostolska o powołaniu i misji świeckich w Kościele i świecie Christifideles laici, 30.12.1998, nr 46. 
zależy od nich, na fundamencie miłości i dobra. Nowa ewangelizacja jest wizją przyszłości, głoszeniem Ewangelii, odnową i coraz odważniejszym wkraczaniem na ścieżki prowadzące do Pana.

\section{MŁODOŚĆ AREOPAGIEM NOWEJ EWANGELIZACJI}

Jan Paweł II w encyklice Redemptoris missio posługuje się pojęciem „areopag” w kontekście sfer, które potrzebują nowej ewangelizacji. Zalicza do nich między innymi świat środków przekazu, które są głównym nośnikiem informacji, a także zaangażowanie na rzecz ochrony świata stworzonego oraz praw człowieka i narodów. Misją Kościoła jest ich uformowanie, by były zdolne do budowania świata opartego na Ewangelii.

Młodość jest okresem bardzo dynamicznym, ponieważ młodzi ludzie zaczynają sami decydować o swoim losie, a zatem dokonują różnych wyborów, czemu towarzyszy wewnętrzne zmaganie między tym, co dobre, a co złe . Mimo różnych zagrożeń (takich jak ucieczka w narkotyki czy nihilizm), które opanowały świat, chcą budować kulturę przyszłości ${ }^{6}$, której pierwszym etapem jest odkrycie prawdy. Podczas Światowych Dni Młodzieży młodzi ludzie mogą nauczyć się jak za nią podążać, ponieważ mają okazję podjąć dialog z Chrystusem. Młodzież nieustannie poszukuje prawdy, bo to właśnie na niej opiera się wielkość człowieka i jego god-

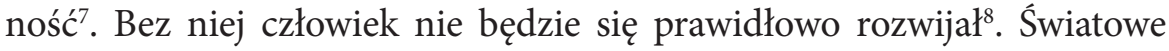
Dni Młodzieży jako wielki dar wiary są dla młodych także okazją, aby głębiej poznać się nawzajem i zjednoczyć się mimo różnić kulturowych. Benedykt XVI w encyklice Caritas in veritate zaznaczył, że właśnie w miłości trzeba znaleźć prawdę i ją wyrażać, a z kolei miłość należy cenić i żyć nią w świetle prawdy. Nie można traktować miłości tylko jako sumy przyjemnych emocji, bo nią nie jest; jeżeli przestaje być traktowana jako stała postawa względem innych, wtedy traci znaczenie i niszczy ludzkie

5 Zob. tenże, Adhortacja apostolska o katechizacji w naszych czasach Catechesi tradendae, 16.10.1979, nr 39.

6 Zob. tamże, nr 35.

7 Zob. tenże, List apostolski do młodych całego świata z okazji Międzynarodowego Roku Młodzieży Parati semper, 31.03.1985, nr 12.

${ }^{8}$ Zob. Franciszek, Encyklika o wierze Lumen fidei, 29.06.2013, nr 24. 
relacje. Miłość trzeba rozwijać w prawdzie, a ponieważ to Bóg jest Prawdą, rezygnacja z niej jest odebraniem Bogu należnego Mu miejsca9. Bez Boga człowiek nie może odnaleźć celu życia i dojrzewać do tego, co jest ważne i co stanowi podstawę prawidłowego funkcjonowania w świetle Ewangelii.

Zagrożeniem niesionym przez kulturę pozbawioną prawdy jest utożsamianie dobra $\mathrm{z}$ tym, co $\mathrm{w}$ danej chwili przyjemne, a zła $\mathrm{z}$ tym, co jest przeszkodą w zaspokojeniu osobistych pragnień ${ }^{10}$. Podczas Światowych Dni Młodzieży młodzi mogą spotkać się z Prawdą i dzięki niej wyznaczyć właściwy kierunek rozwoju swojego życia.

Drugim etapem w budowaniu przyszłości jest proces podążania za prawdą, czyli kroczenie za Chrystusem. Serce każdego człowieka powinno być otwarte na naśladowanie Jego czynów. W tym stadium ważna jest pokora, która asystuje temu procesowi poprzez wyrzeczenie się ziemskich dóbr. Św. Grzegorz Wielki pisze: „Chciałbym was zachęcić do porzucenia wszystkiego, ale nie śmiem. Jeśli przeto nie możecie opuścić wszystkich spraw tego świata, zatrzymajcie je tak, aby one was na świecie nie zatrzymywały, abyście dobra ziemskie posiadali, a nie byli przez nie posiadani; aby wszystko, co wasze, poddane było duchowi, nie zaś, by on, skrępowany miłością do świata, stał się podległych sobie spraw zupełnym niewolnikiem. Niech przeto dobra doczesne będą używane, wieczne - upragnione. Dobra ziemskie niech będą usługującymi w drodze, wieczne - upragnionymi u celu"11. Ważne jest także tłumienie własnego egocentryzmu.

Wymogiem dążenia do prawdy jest jej głoszenie i dawanie o niej świadectwa własnym życiem, co jest możliwe dzięki łasce i prawdzie danej przez Chrystusa w orędziu tajemnicy paschalnej ${ }^{12}$. Każdy człowiek podejmuje decyzje zgodne $\mathrm{z}$ jego sumieniem, ale musi to być sumienie właściwie uformowane, kształtowane w świetle prawdy; trzeba umieć odróżnić dobro od zła, podjąć trud odkrycia najważniejszych wartości.

9 Jan Paweł II, Miłość i odpowiedzialność, Lublin 1982, s. 4.

${ }_{10}$ Zob. Jan Paweł II, Chrystus nadzieja, która nie zawodzi, przemówienie, Denver 1993, OsRomPol 14 (1993) 11, s. 32.

11 Homilia św. Grzegorza Wielkiego do Ewangelii (księga 2, homilia 36, 11-12).

12 Zob. Jan Paweł II, Kościół i Papież oczekuja od was, abyście wyznawali Chrystusa, przemówienie, Manila 1995, OsRomPol 16 (1995) 3, s. 19. 
To właśnie młodzi ludzie podążający za nauką Chrystusa dają przeświadczenie o szansie zgodnego z nią rozwoju przyszłego świata.

$\mathrm{W}$ dzisiejszych czasach młodzi ludzie $\mathrm{z}$ różnych zakątków świata doznają cierpienia zarówno w sferze duchowej, psychicznej, jak i fizycznej. Kataklizmy, bieda, rozłąka rodziców, brak możliwości rozwoju, samotność - to niektóre z przykładów. Cierpienie jako konsekwencja grzechu pierworodnego pojawia się w życiu każdego pokolenia. I chociaż ludzie starają się uniknąć cierpienia, zapobiec mu lub je zwalczyć, często pozostają bezradni. Zwłaszcza cierpienia moralnego, którym jest ból duszy, człowiek nie może pokonać sam ${ }^{13}$. Poszukuje odpowiedzi na pytanie o sens cierpienia, zwłaszcza niezawinionego. Znaleźć ją może w osobie i dziele zbawczym Chrystusa, w Jego obecności, która jest pełna miłości ${ }^{14}$. Światowe Dni Młodzieży są dla młodych okazją, by nauczyli się, jak postrzegać w świetle wiary cierpienie własne i innych i jak zachowywać się w stosunku do ludzi, którzy potrzebują pomocy. Cierpienie przynosi ból i przygnębienie, ale zjednoczone ze zbawczą męką Jezusa Chrystusa, staje się współzbawianiem świata i może wydać owoce w postaci dojrzałości charakteru. Kiedy jednoczymy cierpienie z Jezusem, opieramy swoje czyny na Jego Miłości i bardziej troszczymy się o drugiego człowieka. Według Benedykta XVI, cierpienie jest także uczeniem się nadziei ${ }^{15}$. Kiedy człowiek będzie budował przyszłość w oparciu o naukę samego Boga i na silnej wierze, to przeżywany ból nie będzie prowadził do desperacji, ale do ufności, że będzie lepiej. Doskonaląc cnotę nadziei, w trudach i niesprzyjających okolicznościach, dostrzega się szansę na jej ugruntowanie. Wyraża się ona w wierze, że Bóg pociesza pogrążonych w cierpieniu i poprzez swoją miłość otwiera każdemu drogę do pójścia za Nim.

Odnalezienie, dostrzeżenie zbawczego sensu cierpienia jest także nieodłącznym warunkiem dostrzegania go w cierpieniu innych. Zaakceptowanie przez człowieka w jakiś sposób cierpienia bliźniego powoduje, że staje się ono też jego udziałem, a cierpienie zostaje przeniknięte duchem

13 Zob. tenże, List apostolski o chrześcijańskim sensie ludzkiego cierpienia Salvifici doloris, 11.02.1984, nr 5.

14 Zob. tamże, nr 13.

15 Zob. Benedykt XVI, Encyklika o nadziei chrześcijańskiej Spe salvi, 30.11.2007, nr 35-40. 
miłości ${ }^{16}$. Zrozumienie sensu cierpienia oparte jest zatem na miłości i daje radość. Chrześcijanin wie, że nie da się wyeliminować cierpienia, ale może ono nabrać sensu, może stać się aktem miłości, powierzeniem się w ręce Boga, który nas nie opuszcza, i tym samym być etapem wzrostu wiary i miłości ${ }^{17}$. Podczas Światowych Dni Młodzieży formacja duchowa opiera się właśnie na tym powierzeniu się w ręce Boga, na oddaniu się Jezusowi. Prowadzi to do naśladowania Jezusa także w służbie tym, którzy potrzebują pomocy, wsparcia. Takiej postawy młodzi ludzie mogą się nauczyć w czasie Światowych Dni Młodzieży, kiedy dzięki zaangażowaniu w wolontariat, towarzyszący ich organizacji i przebiegowi, uczą się podawać dłoń tym, którzy tego potrzebują; są zachęcani, aby z odwagą i entuzjazmem dążyć do posługi bliźnim, która oparta jest na dobrych czynach. Można liczyć na to, że doświadczenia wyniesione z udziału w wolontariacie pozostawią trwałe skutki; każde dobrowolne działanie na rzecz innych przybliża bowiem człowieka do coraz doskonalszego wypełniania przykazania miłości.

Pomoc cierpiącemu jest dla młodych bezcenną szkołą miłości, otwarciem się jeszcze bardziej na podążanie drogą samego Boga i zbliżeniem się do Niego. Przykładem staje się Jezus Chrystus, pytający niewidomego: „Co chcesz, abym ci uczynił?” (Mk 10,51), stający przed cierpiącym człowiekiem w postawie sługi. Człowiek uformowany na Jego wzór wzrasta w miłości i nie lęka się już problemów, bo żyje wiarą, że w trudnych chwilach Chrystus jest z nim zawsze obecny. Młodzież doświadczająca cierpienia i spotykająca się z nim może odnaleźć siły w podążaniu za Jezusem i stawać się „,solą ziemi i światłością świata” (Mt 5,13-14), ukazywać możliwość budowania własnego życia na fundamencie miłości.

Światowe Dni Młodzieży są dla młodych szansą na odkrycie prawdy i podążanie za nią; w świetle zadań nowej ewangelizacji to szansa bardzo ważna. Młodzież musi sobie uświadomić, że to od niej zależy przyszły świat, że decyzje, jakie podejmą, będą skutkować w następnych pokoleniach. Kościół ma wielkie zadanie do spełnienia. Musi pomóc młodym ludziom zrozumieć doświadczane przez nich cierpienia i odnajdywać $\mathrm{w}$ nich szansę na duchowe owoce, a także prowadzić do podejmowania

16 Tamże, nr 38.

17 Zob. Franciszek, Encyklika o wierze Lumen fidei, 29.06.2013, nr 56. 
mądrych decyzji, które ukształtują ich serca i staną się podwaliną do budowania świata zgodnego z wolą Bożą. Ukrzyżowany Jezus, proszący o miłosierdzie dla swych oprawców, jest dla młodych ludzi drogowskazem, jak postępować wobec innych; uczy, jak ważne jest przezwyciężanie w sobie chęci odwetu i innych złych emocji. To właśnie w cierpieniu Chrystusa za grzechy ludzi znajdują się wskazówki do podążania drogą miłości.

\section{POTRZEBA WZORCÓW DUCHOWYCH NA DRODZE NOWEJ EWANGELIZACJI}

Na rozwój człowieka wpływa otoczenie, w jakim on funkcjonuje. To inne osoby są dla młodych ludzi przykładem, jak należy postępować, to od nich uczą się wartości. Przekazywane wzory zachowań, przeżywane doświadczenia uczą, jak budować przyszłe życie, więc ważne jest, aby był to przekaz skłaniający do postępowania w wierze, miłości i dobru. Osoby, których życie oparte jest na Ewangelii, stanowią dla młodych przykład, zachętę, aby i oni tak samo działali. Zatem wzorce duchowe są pomocne na drodze nowej ewangelizacji.

W dzisiejszym świecie zagrożeniem dla młodzieży jest przedstawianie przez środki masowego przekazu fałszywych idoli, ukazywanie życia gwiazd rozrywki jako ideału, wzoru do powielania. Podczas Światowych Dni Młodzieży widać jednak, że wielu młodych nie podąża za przynętami, jakie oferuje świat mediów, ale pragnie autentycznych świadków życia chrześcijańskiego i z entuzjazmem przyjmuje ukazywane im postacie, prawdziwe wzorce osobowe, wyrażając gotowość naśladowania ich.

Najwspanialszym wzorem osobowym jest Jezus Chrystus. Światowe Dni Młodzieży odgrywają bardzo ważną rolę w procesie nowej ewangelizacji, bo w tym czasie młodzi ludzie mogą jeszcze bardziej zagłębić się w lekturę Pisma Świętego, poznawać czyny Jezusa i rozważać Jego słowa, a dzięki temu podjąć decyzję o naśladowaniu Go własnym życiem, a także poznać wiele świadectw ukazujących bogactwo Ewangelii i możliwość życia według niej.

Młodzi ludzie potrzebują prawdziwych świadków, którzy są autentycznymi przykładami życia wiarą. Podczas Światowych Dni Młodzieży, które są jedną z dróg nowej ewangelizacji, przedstawia się ich 
jako wzory. Matka Boża jako świadek wiary jest na pierwszym miejscu i uczy, aby w każdym momencie życia mówić Jezusowi „tak”. Ona całe życie poświęciła swojemu Synowi, zawierzyła się Mu i była przy Nim nieustannie obecna. Maryja jako Szafarka łask wyprasza je u Boga dla wszystkich ludzi i daje wskazówki do osiągnięcia wiekuistego szczęścia. Jest Przewodniczką i Matką każdego człowieka, obecna w każdej chwili. Symbolem Światowych Dni Młodzieży jest Ikona Matki Bożej. Jest to potwierdzenie zawierzenia się Maryi, wstawiającej się za nami w każdym miejscu. Maryja uczy czynów opartych na miłości i wychowuje, by kierować się dobrocią i sercem. Szkoła Maryi pozwala odkryć to, czego Chrystus oczekuje od każdego człowieka; uczy, jak stawiać Go na pierwszym miejscu i zwrócić się ku Jego słowu ${ }^{18}$. Młodzi ludzie podążający za Matką Bożą dojrzewają do prawdziwej miłości i rozwijają się w prawdzie. Światowe Dni Młodzieży są wyjątkową szansą, by nauczyć się zawierzać wszystkie swoje troski Maryi, która oręduje za każdym człowiekiem u Boga. Matka wszystkich ludzi jest prawdziwym wzorem do naśladowania, to Ona całym swoim życiem pokazała, jak budować cywilizację opartą na wierze, jak nawet w najtrudniejszych chwilach można odnaleźć siły: dzięki obecności Chrystusa w sercu i otwarciu się na Jego miłość i działanie.

Światowe Dni Młodzieży ukazują także wzory świętych, którzy są przykładem prowadzenia prawdziwie chrześcijańskiego życia. Świadectwa świętych pomagają w kroczeniu drogami nowej ewangelizacji. Młodzi ludzie mogą nauczyć się postępować tak jak oni i odnaleźć wszelkie bogactwa, które stanowią podstawę ożywienia wiary. Jan Paweł II nauczał o świętości jako o darze, który jest powierzony wszystkim uczestnikom Kościoła $^{19}$. W życiorysach świętych Kościoła można odnaleźć wiele trudności, które napotkali w życiu, przekonać się, że nie zawsze było im łatwo. Jednak poprzez modlitwę i żywą wiarę odnajdywali siły, które oświecały ich serca i prowadziły do Boga. Często wielu młodych ludzi zbacza z Chrystusowej drogi, kiedy staje się dla nich trudna do przejścia.

${ }_{18}$ Zob. A. Strukelj, Nowa ewangelizacja a Maryja, w: Nowa ewangelizacja, tłum. L. Balter, „Communio”, Międzynarodowy Przegląd Teologiczny, Poznań 1993, nr 8, s. 373.

${ }_{19}$ Jan Paweł II, Duch Święty, On was wszystkiego nauczy (J 14,26), orędzie na ŚDM cyt., Watykan 1997, OsRomPol 19 (1998) 2, s. 7. 
To właśnie święci są przykładem, że nie warto się poddawać, ale trzeba stawić czoła wszystkim swoim słabościom.

Młodzi ludzie w obecnych czasach stoją przed wielkim wyzwaniem, jakim jest pogłębienie wiary i podążanie ku doskonałości. Wszyscy są „powołani do świętości”. To Chrystus, który mówi: „Ja jestem światłością świata. Kto idzie za Mną, nie będzie chodził w ciemności, lecz będzie miał światło życia" (J 8,12), powinien być na pierwszym miejscu. Jednak jest to osobista decyzja każdego człowieka, którą sam musi podjąć. Obecność Boga w życiu młodych ludzi pozwoli im bardziej dostrzegać to, co najważniejsze, a nie to, co materialne. Należy wskazywać młodzieży za przykładem Benedykta XVI, że nie ideologie, ale wpatrywanie się w Boga, który jest wieczną miłością, zbawia świat ${ }^{20}$.

Wzór Matki Bożej i świętych daje szansę młodym ludziom na odnalezienie się w dzisiejszym świecie, który na pierwszym miejscu stawia posiadanie dóbr materialnych, a w pogoni za nimi zamyka serca ludzkie, promuje bezwzględną rywalizację powodującą nienawiść. Święci służyli Bogu i poświęcali się ludziom, a więc są autentycznym przykładem, że podążając za prawdą, można zbudować lepszy świat i umocnić się w wierze. Młodzież poprzez wzory świętych może dostrzec sposoby na uczenie się odkrywania życia w świetle prawdy, a nie uciekania się do kłamstwa.

Światowe Dni Młodzieży są potwierdzeniem autorytetu, jakim wśród młodych ludzi cieszy się papież ${ }^{21}$. Młodzież z uwagą słucha nauk papieża i z energią to nauczanie odsłania. Jan Paweł II mówił, że Kościół chce nawiązać dialog z nowymi pokoleniami,by przekazywać postawy, które prowadzą do zbawienia ${ }^{22}$. Zarówno Jan Paweł II, jak i Benedykt XVI podczas swoich pontyfikatów ukazywali dialog ekumeniczny jako główne zadanie prowadzące do zjednoczenia i wspólnej modlitwy. Wszyscy chrześcijanie powinni razem dawać świadectwo o Chrystusie i odwoływać się do Pisma Świętego. Benedykt XVI sygnalizował, że wierzący powinni

${ }^{20}$ Benedykt XVI, Święci zmieniają Kościót i świat, przemówienie Marienfeld 2005, OsRomPol 26 (2005) 10, s. 25.

${ }^{21}$ Zob. K. Olbrycht, Ojciec Święty - wychowawca młodzieży, Ethos 6 (1993), nr 3, s. 127-140. O roli autorytetu w wychowaniu traktuje: P. Góralczyk, Wychowawcza etyka seksualna, Ząbki 2000, s. 28-37.

${ }^{22}$ Jan Paweł II, Jak Ojciec Mnie posłał, tak i Ja was posyłam (J 20,21), orędzie na ŚDM w Manili, OsRomPol 15 (1994) 2, s. 4. 
dostrzegać to, co ich łączy, a nie to, co ich rozdziela ${ }^{23}$. Obecny papież Franciszek nawołuje młodzież do poświęcania szczególnej uwagi ubogim, do dostrzegania ich potrzeb. Ważne jest także, aby przekazać młodym ludziom, że powinni budować świat na pokoju. Drogowskazy do wypełniania tego zadania można odszukać właśnie podczas Światowych Dni Młodzieży w nauczaniu papieża, którego autorytet prowadzi młodzież do tolerancji i szacunku wobec drugiego człowieka.

Pomocą dla młodych w prowadzeniu chrześcijańskiego życia są także kapłani, duszpasterze i osoby konsekrowane. Na wzór Jezusa są oni dobrymi pasterzami, którzy wskazują ścieżki do podążania Chrystusową drogą. Głoszą oni Jego naukę i są przewodnikami w procesie kształtowania życia w wierze; sami kroczą za głosem Jezusa, dlatego są wiarygodni zachęcając każdego człowieka do pójścia za Nim.

Ważną rolę w procesie kształtowania osobowości młodego człowieka odgrywają rodzice i wychowawcy. Relacje między nimi oparte na porozumieniu pełnią zasadniczą funkcję $\mathrm{w}$ budowaniu przez młodzież przyszłego życia opartego na prawdzie. To rodzice przekazują najważniejsze wartości dzieciom, które biorą z nich przykład. To matka i ojciec są pierwszymi wychowawcami młodych ludzi, więc spoczywa na nich obowiązek wychowania ich w wierze, by umieli w swoim życiu kierować się prawdziwą miłością i dobrem. Podczas Światowych Dni Młodzieży porusza się kwestie związane z zagrożeniami współczesnego świata, zwracając uwagę, jak ważna w wychowaniu młodego pokolenia jest rola rodziców, którzy poświęcają dzieciom swój czas i prowadzą ich drogami formacji duchowej, ponieważ „wszystko zaczyna się w waszej rodzinie, kiedy Jezus mówi po raz pierwszy «Ja was posyłam!»"24.

\section{SPOGLĄDANIE Z NADZIEJĄ NA MŁODYCH}

Papież Franciszek w Orędziu na Światowe Dni Młodzieży w Krakowie podkreślił, że ufa młodym ludziom i to właśnie w nich widzi

${ }^{23}$ Zob. Benedykt XVI, Dekalog naszym wspólnym dziedzictwem i zobowiązaniem, przem. w synagodze podczas ŚDM, Kolonia 2005, OsRomPol 26 (2005) 10, s. 16-17.

${ }^{24}$ Jan Paweł II, Bądźcie znakiem nadziei dla Kościoła i świata, homilia, Manila 1995, OsRomPol 16 (1995) 3, s. 21-22. 
nadzieję dla świata. Jan Paweł II już na początku swojego pontyfikatu mówił do młodzieży: „Wy jesteście nadzieją świata, nadzieją Kościoła, wy jesteście moją nadzieją” (Anioł Pański 22.10.1978). W młodości tkwi ogromne bogactwo, ponieważ ten okres jest kluczowy w rozwoju każdego człowieka. To właśnie wtedy młodzież stawia wiele pytań odnoszących się do celu i sensu życia. Wkraczając w dorosłe życie, szuka drogi, która poprowadzi ją do wybranego celu. Zadaniem Światowych Dni Młodzieży jest ugruntowanie $\mathrm{w}$ młodych przekonania, że tym wybranym celem ma być ich udział w przemianie świata, by wszyscy zostali zbawieni.

Ważnym elementem $\mathrm{w}$ budowaniu przyszłości jest zachowanie przez młodych ludzi czystości serca. Na kartach Pisma Świętego serce utożsamiane jest $\mathrm{z}$ sumieniem, a czystość serca $\mathrm{z}$ umiłowaniem Boga nade wszystko i z prawdziwą miłością bliźniego ze względu na Boga ${ }^{25}$. Ważnym zadaniem jest zatem dbanie o czystość serca, o uwolnienie go od opisanej przez św. Jana potrójnej pożądliwości: żądzy ciała, żądzy oczu i pychy żywota. Nie bez powodu Jezus ostrzega: „Gdzie bowiem jest twój skarb, tam będzie i serce twoje” (Mt 6,21). Świat stawia przed młodymi ludźmi wiele pokus, nakłaniając do zła przez fałszowanie pojęcia wolności. Pomocą w walce o czystość serca są łaski wypływające z sakramentów świętych.

Panowanie nad swoimi emocjami, nad samym sobą pozwala na osiągnięcie pokoju i przybliża do zachowania czystości ${ }^{26}$. Grzech prowadzi do uruchomienia we wnętrzu człowieka procesu starzenia się, otępienia, które skutkuje niemożnością zgłębiania Bożej Miłości ${ }^{27}$. Patrzenie sercem i wyzbycie się oślepiającej pychy i uprzedzeń pozwala spotkać samego Boga. Obranie przez młodych ludzi właśnie takiej drogi otworzy ich na walkę z własnymi słabościami, ale także otworzy ich oczy na niezgłębioną miłość Boga. Zachowanie czystości jest znakiem dojrzałości i protestem wobec zachowań łamiących normy moralne. Ważne jest, aby już w okresie młodości starać się tę czystość zachowywać, by umieć kierować się właściwymi zasadami postępowania także w dorosłym życiu.

25 Zob. Jan Paweł II, Homilia wygłoszona w Sandomierzu, 1999, w: Jan Paweł II, Polska 1999, Warszawa 1999, s. 140-147.

${ }^{26}$ KKK 2339 ; zob. Papieska Rada ds. Rodziny, Ludzka płciowość: prawda i znaczenie, Łomianki 1995, s. 13-14.

${ }_{27}$ Zob. Jan Paweł II, Jako apostołowie nowej ewangelizacji budujcie cywilizacje miłości, przemówienie, Buenos Aires 1987, OsRomPol 8 (1987), nr 6, s. 26. 
Dzięki czystości serca człowiek jest w stanie służyć bliźniemu. Podczas Światowych Dni Młodzieży będących formą duszpasterstwa młodego pokolenia, które wspiera ich formację ${ }^{28}$, młodzi uczą się, jak to oddanie siebie dla innych pielęgnować, ale przede wszystkim mają szansę uświadomić sobie, na czym polega prawdziwe człowieczeństwo. W czasie tych wielkich wydarzeń Ojciec Święty poprzez swoją katechezę kieruje do nich naukę, na której powinno opierać się ich życie. Jest ona trudna, ponieważ „wymaga wyrzeczeń i złożenia w ofierze własnego życia, a także, gdy to konieczne, oddania go za Chrystusa" ${ }^{29}$. Młodzi ludzie często skupiają się tylko na własnym ego, nie widząc potrzeb innych. Wynika to z załamania wiary i życia duchowego, co w konsekwencji wiąże się z uwstecznieniem. W młodości częstym zjawiskiem jest kryzys wiary. Według św. Tomasza: „Wiara jest to sprawność duchowa, mocą której rozpoczyna się w nas życie wieczne, a która czyni nasz umysł przylegającym do tego, co nieoczywi-

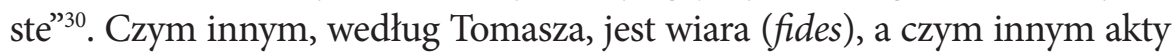
(credere), które z niej wypływają. Kryzys wiary to znak, że psychologiczne przyjęcie przekonania o istnieniu Boga nie znajduje odzwierciedlenia w czynach codziennego życia. Może to prowadzić do postrzegania rzeczy materialnych jako wartości wyższych niż etyczne. Jednak Światowe Dni Młodzieży mogą stać się okazją do osiągnięcia dobrych skutków kryzysu, czyli do nawrócenia, dzięki spotkaniu z żywym Chrystusem we wspólnocie wierzących. Dzięki temu chrześcijańskie życie młodego pokolenia na drodze nowej ewangelizacji może oprzeć się na miłości Chrystusa Ukrzyżowanego, który poświęcił swoje życie dla każdego człowieka.

Dzisiejszy świat potrzebuje świadectw osób duchownych i konsekrowanych, które żyją służbą drugiemu człowiekowi i przekazują prawdziwy wymiar powołania. Również osoby powołane do małżeństwa są świadkami miłości. Ewangelista Mateusz przytacza słowa Jezusa: „Tak już nie są dwoje, lecz jedno ciało" (Mt 19,6). Małżonkowie są jednością, w której wzajemnie obdarowują się miłością i są zdolni do przekazywania nowego życia. To właśnie w rodzinie młodzi ludzie powinni odnajdywać

${ }^{28}$ Jan Paweł II, Posynodalna adhortacja apostolska Ecclesia in America, 22.01.1999, nr 93.

${ }_{29}$ Zob. Jan Paweł II, Jako apostołowie nowej ewangelizacji budujcie cywilizacje miłości, dz. cyt., s. 28.

30 Tomasz z Akwinu, (STh 2-2 q.4 a.1). 
najważniejsze wartości. Bezinteresowność jest darem z siebie, dlatego w wychowaniu młodego pokolenia już od samego początku aspekty ofiarności powinny być obecne, mimo że wymaga to trudnej drogi do przejścia. Podczas Światowych Dni Młodzieży to powołanie do służby bliźnim jest wyraźnie podkreślane.

Młodzież, wkraczając w dorosłe życie, nieustannie dokonuje różnych wyborów, dlatego obecność podczas Światowych Dni Młodzieży jest oznaką ich zaangażowania w swój rozwój, który będzie przynosił liczne owoce nie tylko w odniesieniu do ich własnych rodzin, ale także do każdego człowieka. Udział w tym szczególnym spotkaniu młodzieży z Ojcem Świętym pozwala młodym ludziom poczuć, że są odpowiedzialni nie tylko za siebie, ale także za rozwój swojego narodu i kultury, który mogą potwierdzić poprzez chrześcijańską wiarę. Zaangażowanie młodzieży w to życiowe doświadczenie jest oznaką, że chcą budować przyszłość na fundamencie dobra, realizując przykazania Boże.

Młodzi ludzie są nadzieją na odnowę świata, w którym nasila się odrzucanie nauki Boga. Muszą dokonywać świadomych, racjonalnych wyborów. Nowa ewangelizacja polega na głoszeniu Dobrej Nowiny, walce ze złem, przeciwstawianiu się złemu duchowi. Kościół, a więc wszyscy ochrzczeni, powinni prosić Ducha Świętego o łaskę odważnego podążania Chrystusową Drogą. Trzeba przeciwstawiać się grzechowi i chodzić ścieżkami prowadzącymi do miłości i sprawiedliwości. To obecna młodzież będzie kształtować przyszłe społeczeństwo poprzez swój przykład jako rodzice i nauczyciele, ponieważ przejmie wypełnianie tego zadania z rąk własnych wychowawców ${ }^{31}$. Światowe Dni Młodzieży są czasem, kiedy jeszcze głębiej można zastanowić się nad wyborem życiowej drogi ukształtowanej poprzez modlitwę i żywą wiarę.

Podczas Światowych Dni Młodzieży szczególna uwaga kierowana jest w stronę Matki Bożej, która jest Gwiazdą Nowej Ewangelizacji. Maryja jest matką wszystkich ludzi, całego Kościoła. Zawierzając się matce Jezusa Chrystusa, można odmienić swoje życie, rozwiązać problemy. To Ona jest Przewodniczką i jej troska może pokonywać wszelkie obawy tkwiące w umysłach młodego pokolenia. Wstawiając się za nami u Boga, prosi

${ }^{31}$ Benedykt XVI, Idźcie i nauczajcie wszystkie narody $(M t 28,19)$, orędzie na ŚDM w Rio de Janerio, OsRomPol 34 (2013) 1, s. 14. 
o łaski i poprzez swoją matczyną miłość dodaje otuchy. Młodzi ludzie w walce $\mathrm{z}$ grzechem i złem tego świata mogą znaleźć ratunek u Matki Bożej, która nie opuszcza człowieka, lecz pomaga odpowiedzieć na Chrystusowe wezwanie do życia zgodnego z wolą Bożą.

Młodzi ludzie są nadzieją, aby zbudować przyszłość na fundamencie żywej wiary. Trzeba pomóc im odnajdywać odpowiedzi na pytania, na które sami nie są w stanie odpowiedzieć. Jan Paweł II, kierując do młodzieży słowa: „Musicie od siebie wymagać, nawet gdyby inni od Was nie wymagali” ${ }^{32}$, zachęca ją do dążenia, by stawać się coraz lepszymi. Poprzez samokontrolę młodzież jest w stanie kierować swoim życiem, więc ważne jest, aby te najważniejsze wartości uznała za własne i opierała swoje życie na nauce Boga. „Jeśli będziecie tym, czym macie być, zapalicie cały świat”. Tymi słowami Jan Paweł II dał wyraz przekonaniu, że podczas Światowych Dni Młodzieży młodzi ludzie uświadamiają sobie, jak należy zbudować przyszłość prowadzącą do Chrystusa ${ }^{33}$.

\section{PODSUMOWANIE}

Światowe Dni Młodzieży pozwalają odkryć drogę prawdy i nią podążać. Warto zadać sobie pytanie: Czy Światowe Dni Młodzieży są potrzebne i jakie owoce duchowe rodzą w młodych? Podczas spotkań z Ojcem Świętym młodzi ludzie mogą z innej perspektywy spojrzeć na cierpienie, by je zrozumieć i szukać jego sensu, a także jeszcze bardziej otworzyć się na miłość i uprzejmość względem drugiego człowieka. Podążając drogami wiodącymi do Boga, prowadzą swoje życie do wzrostu i odkrywają, co tak naprawdę oznacza dobrze czynić. Młodzież może lepiej poznać siebie i otworzyć swoje serca na głos Jezusa.

W czasie Światowych Dni Młodzieży młodzi mają okazję spotkać wielu świadków wiary, którzy poprzez swoje doświadczenia przybliżają im Chrystusa. Te wydarzenia są potrzebne, aby młodzież jeszcze bardziej

${ }^{32}$ Zob. Jan Paweł II, Maryjo, Królowo Polski, jestem przy Tobie, pamiętam, czuwam!, przemówienie do młodzieży w czasie Apelu Jasnogórskiego, Częstochowa 1983, w: Pokój Tobie, Polsko! Ojczyzno moja!, Watykan 1983, s. 78.

${ }^{33}$ Jan Paweł II, Żyjcie Eucharystia, dając świadectwo miłości, homilia, Rzym 2000, OsRomPol 21 (2000) 10, s. 24. 
otworzyła się na Bożą Miłość i wzrastała w niej. Przyszłe życie, które oni sami ukształtują, będą budować na wartościach, zdobytych na drogach odnajdywania sensu i celu życia. Duchowe owoce, które rodzą w młodych Światowe Dni Młodzieży, szczególnie miłość, czystość, pokój, dobroć i wierność, są dobrym kierunkiem rozwoju młodych ludzi i otwierają serca na chrześcijańskie wartości.

Papież Franciszek w swojej apostolskiej posłudze wypowiedział słowa, które powinny zagościć w umysłach młodych ludzi: „Chciałbym jednakże zastanowić się przede wszystkim nad faktem, że Duch Święty jest niewyczerpanym źródłem życia Bożego w nas. Człowiek wszystkich czasów i wszystkich miejsc pragnie życia pełnego i pięknego, sprawiedliwego i dobrego, życia, któremu nie groziłaby śmierć, ale które mogłoby dojrzewać i rozwijać się aż do swej pełni. Człowiek jest jak wędrowiec, który przemierzając pustynię życia, pragnie wody żywej i wytryskującej, świeżej, zdolnej, by dogłębnie zaspokoić jego głębokie pragnienie światła, miłości, piękna i pokoju. Wszyscy odczuwamy to pragnienie! I Jezus daje nam tę wodę żywą: jest nią Duch Święty, który pochodzi od Ojca i którego Jezus wlewa w nasze serca" ${ }^{34}$. Duchowe owoce Światowych Dni Młodzieży są źródłem życia i świętości.

Warto także odpowiedzieć sobie na pytanie: Czy nowa ewangelizacja jest wezwaniem $\mathrm{w}$ ciągłym poszukiwaniu nowych dróg realizacji życia duchowego? Ważna jest rola osobowych wzorców, ponieważ to święci swoim życiem pokazują różne drogi podążania za Chrystusem i umocnieniem z Nim swoich relacji. Nowa ewangelizacja jest procesem dynamicznym, chce docierać ze swoją nauką do wszystkich ludzi na całej ziemi i przekazywać w nowej formie Ewangelię, zachowując jej zasadniczy sens. Jest ciągłym poszukiwaniem nowych dróg realizacji życia duchowego, pokazuje wiele sposobów na uczynienie swojego życia lepszym, wartościowszym i opartym na solidnym fundamencie nauki Chrystusa, który sam o sobie mówił: „Ja jestem drogą i prawdą, i życiem” (J 14,6).

Streszczenie. Światowe Dni Młodzieży są jedną z dróg do realizacji tego wezwania - nowej ewangelizacji. Młodzież z całego świata spotyka się z papieżem, by odkryć drogę prowadzącą za Chrystusem. Te wydarzenia są istotne dla życia Kościoła, ponieważ

${ }^{34}$ Franciszek, Katecheza podczas cotygodniowej audiencji ogólnej, Watykan, 08.05.2013. 
młodzi ludzie odkrywają drogę prawdy. Podczas tej formacji duchowej młodzież może usłyszeć wiele świadectw, które są pomocne w rozwoju chrześcijańskiego życia. Światowe Dni Młodzieży są darem, dzięki któremu można odkryć nowe siły do ożywienia wiary.

W dzisiejszych czasach młodzi ludzie zmagają się z różnymi pokusami, mają wiele lęków i trosk. Należy wpoić im najważniejsze wartości, przekazać swoje doświadczenia, aby mogli zbudować przyszły świat, który zależy od nich, na fundamencie miłości i dobra. Nowa ewangelizacja jest wizją przyszłości, głoszeniem Ewangelii, odnową i coraz odważniejszym wkraczaniem na ścieżki prowadzące do Pana.

W niniejszym artykule podjęto to zagadnienie w następujących punktach: młodość areopagiem nowej ewangelizacji; potrzeba wzorców duchowych na drodze nowej ewangelizacji; spoglądanie z nadzieją na młodych.

Słowa kluczowe: Duchowość młodzieży; Światowe Dni Młodzieży; wzorce duchowe; nowa ewangelizacja.

Abstract. Calls of the New Evangelisation and the gift of the World Youth Day. The World Youth Day is one of the ways that makes this call - the new evangelisationcome true. Young people come from the whole world to meet the Pope to discover their way of life following Christ. These events are vital to the Church as young people discover the way of truth. During this spiritual formation the young can hear many testimonies which may become helpful in the development of their Christianity. The World Youth Day is a gift thanks to which new powers to revive their faith may be discovered.

Nowadays, young people grapple with many various temptations, they deal with many fears and worries. They should be instilled with the most important values, shared with different experiences so that they can build their future world depending on them and based on the fundaments of love and good. The new evangelisation is the vision of the future, spread of the Gospel, revival and deeper and deeper entering the paths leading to God.

In this article this issue is presented in the following points: youth as the Areopagus of the new evangelisation; the need of spiritual patterns on the way of the new evangelisation; looking at the young with hope.

Keywords: the spirituality of the young; the World Youth Day; spiritual patterns; the new evangelisation. 